\title{
UPAYA MENINGKATKAN HASIL BELAJAR IPA SISWA KELAS V SDN NO. 055999 PSR X KWALA BINGAI KECAMATAN STABAT DENGANMETODE DEMONSTRASI MEDIA AUDIO VISUAL
}

\author{
Ramiah \\ Surel: ramiah@gmail.com
}

\begin{abstract}
ABSTRAK
Penelitian ini bertujuan untuk meningkatkan hasil belajar dan aktifitas belajar siswa pada mata pelajaran IPA di kelas 5 SDN No. 055999 Psr. X Kwala Bingai Kec. Stabat. Penelitian ini adalahPenelitian Tindakan Kelas (PTK) dengan melibatkan dua orang pendamping sebagai pengamat dan membantu peneliti. Hasil penelitian pada siklus II yaitu terjadi peningkatan aktivitas siswa. Meningkatnya persentase partisipasi aktif siswa sejalan dengan meningkatnya kinerja guru. Dengan meningkatnya aktivitas siswa dan juga guru maka prestasi belajar siswa juga meningkat dengan signifikan, sehingga pembelajaran dengan Metode Demontrasi Media Video Audio berhasil dengan baik.
\end{abstract}

Kata Kunci : Peningkatan Hasil Belajar, IPA, Audio Visual

PENDAHULUAN

Dalam Lingkup mikro pendidikan diwujudkan melalui proses belajar mengajar di dalam kelas maupun di luar kelas. Proses ini berlangsung edukatif. Melalui proses belajar mengajar inilah peserta didik akan mengalami proses perkembangan kearah yang lebih baik dan bermakna agar hal tersebut dapat terwujud maka diperlukan suasana proses belajar mengajar yang kondusif bagi peserta didik dalam melampaui tahapan-tahapan belajar secara bermakna dan efektif sehingga menjadi pribadi yang percaya diri, inovatif dan kreatif

Salah satu mata pelajaran yang turut berperan penting dalam pendidikan wawasan, keterampilan dan sikap ilmiah sejak dini bagi anak adalah mata pelajaran IPA. Ilmu
Pengetahuan Alam adalah pengetahuan yang rasional dan objektif tentang alam semesta dan segala isinya.

Sains merupakan cara mencari tahu tentang alam sekitar secara sistematis untuk mengusai pengetahuan, fakta-fakta, konsepkonsep, prinsip-prinsip, proses penemuan, dan memiliki sikapi lmiah. Pendidikan sains bermanfaat bagi siswa untuk mempelajari diri sendiri dan alam sekitar.

Berdasarkan hal tersebut, tergambar jelas tugas yang harus diemban guru-guru di sekolah dasar. Untuk mewujudkan keinginan pembelajaran di Sekolah Dasar yang tertuang di dalam kurikulum, para guru mengemban amanat yang sangat besar. Untuk mencapai pembelajaran yang diinginkan kurikulum, guru 
harus mampu menjadi fasilitator dalam pembelajaran Sains, dan mampu menciptakan pembelajaran yang disesuaikan dengan kebutuhan dan kemampuan siswanya. Dalam pembelajaran, guru harus sebanyak mungkin melibatkan peserta didik secara aktif agar siswa mampu bereksplorasi untuk membentuk kompetensi dengan menggali berbagai potensi, dan kebenaran ilmiah.

Guru sebagai ujung tombak yang menentukan keberhasilan pendidikan dan pengajaran di sekolah, sepertinya belum dapat mengantisipasi keadaan dan keperluansiswa. Dengan pembelajaran pola lama, yaitu proses pembelajaran satu arah yang didominansi oleh guru melalui metode ceramah dan masih kurang melibatkan siswa untuk aktif dalam proses belajar mengajar. Dalam pembelajaran, guru hanya bersikap sebagai pelaksana tugas dalam pembelajaran, bukan memberikan pengalaman belajar yang bermakna kepada siswanya. Guru pun jarang menciptakan model pembelajaran sains dengan pengamatan langsung, percobaan, ataupun simulasi. Akibatnya, sains dianggap sebagai pelajaran hafalan. Padahal, pembelajaran sains dapat menjadi wahana bagi siswa untuk berlatih menjadi ilmuwan, mengembangkan menumbuhkan motivasi, inovasi, dan kreativitas sehingga siswa mampu menghadapi masa depan yang penuh tantangan melalui penguasaan sains. Untuk mencapai tujuan
tersebut, guru tidak boleh mendominasi pembelajaran di dalam kelas, dengan menganggap siswa tidak memiliki pengetahuan awal. Siswa tidak boleh dicekoki dengan hafalan, melalui transfer hal-hal yang tercantum dalam buku teks. Akan tetapi, siswa harus dilatih berpikir dan membuat konsep berdasarkan pengamatan dan percobaan. Jika siswa memberi input, guru harus mau menerimanya dan jangan memutus proses eksplorasi berfikir siswa hanya karena tidak sesuai dengan buku pegangan. Untuk menjadi ilmuwan ataupun untuk belajar diperlukan independensi berfikir. Oleh karena itu, guru seharusnya kreatif dan inovatif dalam meningkatkan kualitas pembelajaran sehingga mampu memenuhi keperluan pembelajaran untuk setiap siswanya.

Dengan metode yang bervariasi inilah siswa akan begairah dalam belajar secara inovatif dan kreatif. Metode yang digunakan dalam interaksi belajar mengajar merupakan salah satu faktor yang menentukan keberhasilan dan kelancaran proses pembelajaran.

Hal ini yang dialami siswa kelas 5 SDN No. 055999 Psr X Kwala Bingai tidak mampu memahami materi yang disampaikan guru khususnya pada mata pelajaran IPA. Usaha untuk meningkatkan pemahaman siswa memerlukan 
metode yang efektif dan efisien. Selainitu, diperlukan pula media pembelajaran yang tepat sehingga siswa dapat menguasai kompetensi yang diharapkan. Penerapan metode demonstrasi dengan menggunakan media audio visual dalam pembelajaran IPA diharapkan membangkitkan rasa ingin tahu dan minat siswa serta motivasi untuk belajar, juga dapat mempermudah siswa dalam memahami materi dan informasi yang disampaikan. Dengan demikian, penerapan metode demonstrasi dengan menggunakan media audio visual diharapkan dapat meningkatkan pemahaman siswa.

\section{METODE PENELITIAN}

Metode penelitian yang digunakan adalah metode penelitian tindakan kelas yang terdiri dari dua siklus, masing-masing siklus terdiri dari perencanaan, pelaksanaan, pengamatan atau evaluasi dan refleksi. Pelaksanaan Penelitian ini dilakukan di SDN No, 055999 Psr X Kwala Bingai yang beralamat di Jalan Makmur Dusun 3 Desa Banyumas KecamatanStabat dalam pembelajaran IPA Siswa kelas 5 SDNNo.055999 Psr X KwalaBingai Semester Ganjil Tahun Pelajaran 2015/2016. Penelitian ini dilakukan selama tiga bulan, mulai Agustus sampai Oktober 2015.

Selama penelitian dilaksanakan observer mengamati aktivitas siswa selama proses pembelajaran berlangsung dan mencatat hal-hal yang penting untuk perbaikan pembelajaran. Dalam melaksanakan proses perbaikan pembelajaran, penulis melakukan berbagai persiapan mencari jalan untuk mengatasi dan memperbaiki masalah tersebut dengan melakukan hal-hal sebagai berikut :1) Menyusun skenario pembelajaran atau Rencana Pembelajaran (RP). 2)Merumuskan tujuan pembelajaran.3)Menetapkan metode dan media pembelajaran. 4)Menyiapkan instrumen evaluasi.

\section{HASIL DAN PEMBAHASAN}

Berdasarkan hasil penelitian yang dilakukan dari pembelajaran siklus pertama hingga yang kedua menunjukkan adanya perubahan baik pada diri siswa, hasil belajar maupun kemampuan profesionalisme gurunya.Perolehan hasil belajar yang dicapai siswa sebanyak 2 siklus dengan KKM 75.

Dari data pada siklus I menunjukkan adanya peningkatan yang semula rata-rata kelas mencapai nilai 69 tetapi pada siklus I rataratanya mencapai 76 . Hasil tes pada siklus I siswa yang mendapat nilai 100 tidak ada, siswa yang mendapat nilai 90 berjumlah 3 orang $(12,50 \%)$, siswa yang mendapat nilai 80 sebanyak 7 orang $(29,71 \%)$, siswa yang mendapatkan nilai 70 sebanyak 6 orang $(25,00 \%)$, siswa yang mendapatkan nilai 60 sebanyak 8 orang $(33,33 \%)$, siswa dan yang dibawah 60 tidak ada. 
Dari data pada siklus II menunjukkan kenaikan yang cukup siginifikan yaitu dimana siswa yang mendapat nilai 90 sebanyak 7 orang $(29,17 \%)$, siswa yang mendapat nilai 80 sebanyak 10 orang $(41,67 \%)$, siswa yang mendapat nilai 70 sebanyak 7 orang $(29,17 \%)$, dari tabel perkembangandapat dikatakan berhasil dan mencapai Kriteria Ketuntasan Minimal (KKM) yaitu 24 orang (100\%). Jadi proses pembelajaran ini sudah tidak perlu diadakan perbaikan lagi.

\section{Grafik. 1.Peningkatan Hasil Nilai dari Siklus I dan Siklus II}

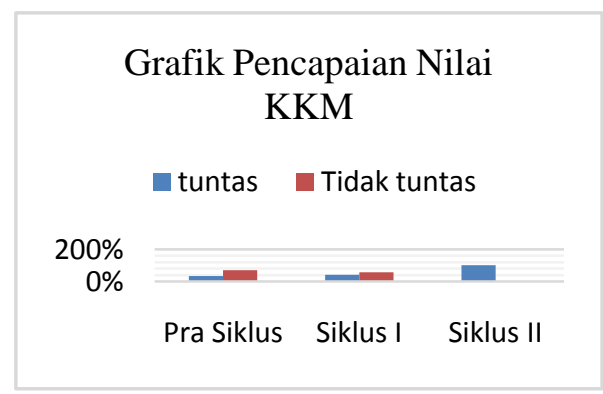

Berdasarkan observasi dan hasil diskusi dengan teman sejawat, diperoleh hasil bahwa perlu diadakannya perbaikan pembelajaran di setiap siklus. Setelah melaksanakan proses pembelajaran dua siklus untuk materi maka terdapat temuan sebagai berikut :

Selama pelajaran pada pra siklus peneliti hanya menggunakan metode ceramah dan tanya jawab. Dengan cara belajar tersebut siswa menjadi lebih cepat bosan dan hasil yang diperoleh juga tidak begitu baik. Hal ini dapat dilihat dari hasil nilai ulangan siklus 1, dimana nilai rataratanya 69 dengan 17 dari 24 siswa mendapat nilai dibawah 75 .

Sedangkan pada siklus I dimana peneliti menggunakan media peraga, para siswa menjadi lebih aktif dalam proses pembelajaran dan juga memahami materi pelajaran yang diajarkan. Hal ini mempengaruhi hasil nilai ulangan pada siklus I ini, dimana nilai rata-rata siswa lebih meningkat menjadi 76 dan terdapat 7 dari 24 siswa yang mendapat nilai dibawah 75.

Apabila diperhatikan perubahan yang terjadi pada nilai siswa pada siklus I dan II menunjukan hal yang positif. Namun hasil yang diperoleh peneliti dinilai masih kurang harus di tingkatkan. Oleh karena itu peneliti mengadakan siklus II dengan memperbaiki strategi dalam proses pembelajaran. Pada siklus II ini peneliti menerapkan metode demonstrasi dengan menggunakan media audio visual dalam proses pembelajaran.

Dengan menggunakan strategi pembelajaran yang baik dan metode pmebelajaran yang bervariatif serta media audio visual siswa menjadi lebih aktif dan menguasai materi pembelajaran lebih bagus bila dibandingkan dengan siklus sebelumnya. Hal ini terlihat dari hasil nilai ulangan yang diperoleh siswa pada siklus II ini, dimana rata-rata yang didapat adalah 86 dan hanya 2 orang siswa yang mendapat nilai kurang dari 75. 
Perkembangan hasil yang diperoleh dari tiap siklus adalah sebagai berikut:

Selama proses pembelajaran, aktifitas guru kurang menarik minat dan perhatian siswa. Dengan metode ceramah guru terlalu banyak memberikan penjelasan tanpa memberikan menggunakan media peraga apapun, guru kurang memberikan kesempatan kepada siswa untuk terlibat dalam proses pembelajaran akibatnya proses pembelajaran kurang berhasil. Siswa hanya diam mendengarkan penjelasan guru. Aktifitas dan kreatifitas siswa kurang terpacu, siswa kurang terlibat dalam proses pembelajaran dan kurang diberi latihan.

Hasil belajar siswa pada pra siklus mata pelajaran IPA rendah, yaitu 69, hal ini karena guru hanya memberikan metode ceramah tanpa menggunakan media yang dapat menarik perhatian siswa.

Hasil pembelajaran pada siklus I ditunjukkan sebagai berikut:

Proses kegiatan belajar mulai menarik perhatian siswa serta terlihat semangat dan aktif dalam mendemonstrasikan alat peraga yang disiapkan oleh guru. Penggunaan media penunjang berupa gambar ternyata mulai menarik perhatian siswa. Siswa mulai aktif menjawab pertanyaaan-pertanyaan yang diajukan guru.

Hasil belajar yang dicapai siswa pada siklus II mengalami peningkatan dibandingkan pada siklus I yakni mencapai rata-rata 76 .

Hasil pembelajaran pada siklus II ditunjukkan sebagai berikut: Proses kegiatan belajar mengajar berbeda dengan siklus I dan II. Guru tidak hanya menerangkan dengan menggunakan metode ceramah, tetapi juga dengan menerapkan metode demonstrasi dengan menggunakan media audio visual. Siswa diberi latihan-latihan dan dalam mendemonstrasikan alat peraga difokuskan pada anak yang daya serapnya rendah, tujuannya agar meningkatkan daya ingatnya.

Metode dan Media yang digunakan lebih konkrit sehingga siswa menjadi terlihat lebih aktif. Guru hanya memancing siswa dengan beragam pertanyaan sesuai gambar yang disajikan dengan menggunakan media audio visual, sehingga siswa termotivasi untuk mengutarakan pendapatnya dan memudahkan bagi siswa untuk memahami materi tentang sistem tata surya. Hal ini berpengarauh pada hasil yang diperoleh untuk rata-rata kelas lebih meningkat dari siklus sebelumnya yaitu mencapai 82 .

Dengan demikian kegiatan perbaikan ini sesuai dengan rencana. Hal ini menunjukkan bahwa pembelajaran sudah dapat dikatakan berhasil

\section{SIMPULAN}

Setelah melakukan Penelitian Tindakan Kelas (PTK) yaitu dua 
siklus untuk pembelajaran mata pelajaran IPA dapat ditarik kesimpulan sebagai berikut :

1. Penggunaan metode dan media pembelajaran secara tepat mampu memicu keterlibatan siswa secara maksimal dalam proses pembelajaran sehingga dapat memotivasi siswa dalam meningkatkan hasil belajarnya.

2. Sebagai motivator dan fasilitator, guru harus dapat menciptakan kondisi agar siswa tertarik untuk belajar, kondisi ini dapat diciptakan jika guru mampu menggunakan metode dan media belajar yang efektif pada pembelajaran tentang sistem tata surya secara tepat.

\section{DAFTAR RUJUKAN}

Abdullah. (1998). Pembelajaran IPA di SD. Jakarta: universitas Terbuka.

Asnawir. 2002. Media Pembelajaran. Jakarta: Ciputat Pers.
Djahiri, Achmad Kosasih. 1999. Strategi Pengajaran Afektif Nilai-Moral V.C.T. dan Games dalam V.C.T. Bandung: IKIP Bandung

Hisyam, Zainid kk. 2004. Strategi Pembelajaran Aktif, Yogyakarta: CTSD

Oemar Hamalik, (2008). Kurikulum dan Pembelajaran. Jakarta : Bumi Aksara

Sulistyorini, S (2007). Model Pembelajaran IPA Sekolah Dasar dan Penerapannya dalam KTSP. Semarang : Tiara Wacana

Suyitno. (2002). Pemilihan Modelmodel Pembelajaran dan Penerapannya di Sekolah. Semarang: Universitas Negeri Semarang.

Syaiful Bahri Djamarah dan Aswan Zain. (2002). Strategi Belajar Mengajar. Jakarta: Rineka Cipta. 